\title{
JURNAL EKONOMI EFEKTIF

\section{PENGARUH PROMOSI DAN HARGA TERHADAP KEPUTUSAN PEMBELIAN DAN DAMPAKNYA TERHADAP KEPUASAN PELANGGAN PADA ALFAMART CABANG CIKOKOL TANGERANG}

\author{
${ }^{1}$ Mada Faisal Akbar, ${ }^{2}$ Ugeng Budi Haryoko \\ Madafaisal84@gmail.com
}

\begin{abstract}
ABSTRAK
Tujuan penelitian adalah untuk mengetahui pengaruh secara parsial dan simultan promosi dan harga terhadap keputusan pembelian. untuk mengetahui pengaruh keputusan pembelian terhadap kepuasan pelanggan, serta untuk mengetahui pengaruh secara parsial dan simultan promosi dan harga terhadap kepuasan pelanggan.

Penelitian ini bersifat Asosiatif dengan pendekatan kuantitatif. Populasi dalam penelitian ini adalah seluruh pelanggan Alfamart Cabang Cikokol, sedangkan sampel yang digunakan dalam penelitian ini sebanyak 100 responden. Tehnik pengumpulan data dengan cara kuesioner, dan Teknik analisis data menggunakan analisis jalur.

Hasil penelitian menunjukan Secara parsial promosi berpengaruh positif dan signifikan terhadap keputusan pembelian pada Alfamart Cabang Cikokol Tangerang. Secara parsial harga berpengaruh negatif dan signifikan terhadap keputusan pembelian pada Alfamart Cabang Cikokol Tangerang. Secara simultan promosi dan harga berpengaruh positif dan signifikan terhadap keputusan pembelian pada Alfamart Cabang Cikokol Tangerang. Secara parsial keputusan pembelian berpengaruh positif dan signifikan terhadap kepuasan pelanggan pada Alfamart Cabang Cikokol Tangerang. Secara parsial promosi berpengaruh positif dan signifikan terhadap kepuasan pelanggan pada Alfamart Cabang Cikokol Tangerang. Secara parsial harga berpengaruh negatif dan signifikan terhadap kepuasan pelanggan pada Alfamart Cabang Cikokol Tangerang. Secara simultan promosi dan harga berpengaruh positif dan signifikan terhadap kepuasan pelanggan pada Alfamart Cabang Cikokol Tangerang.
\end{abstract}

\section{Kata Kunci : Promosi, Harga, Keputusan Pembelian Dan Kepuasan Pelanggan}

\section{ABSTRACT}

The purpose of this study was to determine the effect of partial and simultaneous promotion and price to purchase decision. to determine the influence of purchasing decisions on customer satisfaction, as well as to determine the effect of partial and simultaneous promotion and price to customer satisfaction.

This research is associative with quantitative approach. Population in this research is all customer of Alfamart Branch Cikokol, while sample used in this research counted 100 respondents. Data collection techniques by means of questionnaires, and Techniques of data analysis using path analysis.

The results showed Partially promotion has a positive and significant effect on purchasing decisions on Alfamart Branch Cikokol Tangerang. Partially, the price has a 
negative and significant effect on the purchase decision on Alfamart Branch Cikokol Tangerang. Simultaneously promotion and price have positive and significant effect to purchase decision at Alfamart Branch Cikokol Tangerang. Partially purchase decision have positive and significant effect to customer satisfaction at Alfamart Branch Cikokol Tangerang. In partial promotion has a positive and significant impact on customer satisfaction on Alfamart Branch Cikokol Tangerang. Partially, price negatively and significantly influence to customer satisfaction at Alfamart Branch Cikokol Tangerang. Simultaneously promotion and price have positive and significant effect to customer satisfaction at Alfamart Branch Cikokol Tangerang.

\section{Keywords: Promotion, Price, Purchase Decision And Customer Satisfaction}

\section{PENDAHULUAN}

Industri ritel merupakan industri yang strategis bagi perkembangan ekonomi Indonesia. Karakteristik industri ritel yang tidak begitu rumit membuat sebagian besar rakyat Indonesia terjun ke bisnis ritel. Bisnis ritel adalah penjualan barang secara eceran pada berbagai tipe gerai seperti kios, pasar, department store, butik dan lain-lain. Ditengah berkembangnya bisnis ritel di Indonesia terdapat indikasi bahwa industri ritel nasional lebih didorong oleh pemain baru yaitu ritel modern dibandingkan dengan ritel tradisional. Ritel modern dikelola secara profesional dengan fasilitas yang serba lengkap. Berbeda dengan ritel tradisional yang pengelolaannya kurang profesional. Berdasarkan data pertumbuhan ritel modern yang terus meningkat, terlihat bahwa pembangunan ritel modern tidak memperdulikan toko-toko kecil di sekitarnya seperti toko kelontong.

\section{Tabel 1.1}

Perkembangan Jumlah Gerai Minimarket di Indonesia

\begin{tabular}{|c|c|c|c|c|}
\hline \multirow{2}{*}{ Minimarket } & \multicolumn{4}{|c|}{ Jumlah Gerai (unit) } \\
\cline { 2 - 5 } & $\mathbf{2 0 1 4}$ & $\mathbf{2 0 1 5}$ & $\mathbf{2 0 1 6}$ & $\mathbf{2 0 1 7}$ \\
\hline Alfamart & 5.797 & 6.585 & 8.557 & 12.456 \\
\hline Indomaret & 6.006 & 7.242 & 8.814 & 14.200 \\
\hline
\end{tabular}

Sumber : Asosiasi Pengusaha Ritel Indonesia 2018

Dari data tabel 1.1 yang dipubliksi Asosiasi Pengusaha Ritel Indonesia tahun 2017. Setiap tahunnya gerai minimarket Alfamart terus mengalami peningkatan, pada tahun 2014 berjumlah 5.797unit dan pada tahun 2017 naik hampir 2 kali lipat yaitu sejumlah 12.456 unit. Minimarket merupakan jenis pasar modern yang agresif memperbanyak jumlah gerai dan menerapkan sistem franchise dalam memperbanyak jumlah gerai. Dua jaringan terbesar Minimarket yakni Indomaret dan Alfamart juga menerapkan sistem ini. Persaingan yang semakin ketat, di mana semakin banyak produsen yang terlibat dalam pemenuhan kebutuhan dan keinginan konsumen, menyebabkan setiap perusahaan harus menempatkan orientasi pada kepuasan pelanggan sebagai tujuan utama. Hal ini tercermin dari semakin banyaknya perusahaan yang menyertakan komitmennya terhadap kepuasan pelanggan. Semakin diyakini bahwa kunci utama untuk memenangkan persaingan adalah memberikan nilai dan kepuasan kepada pelanggan melalui penyampaian produk dan jasa berkualitas dengan harga bersaing. Seorang pelanggan, jika merasa puas dengan nilai yang diberikan oleh produk atau jasa, sangat besar kemungkinannya menjadi pelanggan dalam waktu yang lama. 
Tabel 1.2

Data Keluhan Pelanggan Alfamart Cabang Cikokol

\begin{tabular}{|l|l|l|l|l|}
\hline \multirow{2}{*}{ No } & \multicolumn{1}{|c|}{ Keluhan pelanggan } & \multicolumn{3}{|c|}{ Tahun } \\
\cline { 3 - 5 } & \multicolumn{2}{|c|}{$\mathbf{2 0 1 5}$} & $\mathbf{2 0 1 6}$ & $\mathbf{2 0 1 7}$ \\
\hline 1 & Pengambilan debit yang kurang lengkap & 105 & 98 & 235 \\
\hline 2 & Barang expaired & 45 & 30 & 48 \\
\hline 3 & Kasir tidak ramah & 99 & 63 & 77 \\
\hline 4 & $\begin{array}{l}\text { Harga barang yang di display tidak } \\
\text { Sesuai }\end{array}$ & 129 & 116 & 87 \\
\hline 5 & Transaksi Kasir lama & 59 & 195 & 66 \\
\hline 6 & Kembalian dikasih permen & 72 & 49 & 57 \\
\hline 7 & Salah Kembalian uang & 52 & 36 & 35 \\
\hline 8 & Tidak Menanyakan Member & 71 & 73 & 44 \\
\hline 9 & Keamanan dalam parkir & 46 & 22 & 45 \\
\hline 10 & Tidak Memberikan struk belanja & 63 & 105 & 123 \\
\hline \multicolumn{2}{|c|}{ Total } & $\mathbf{7 4 1}$ & $\mathbf{7 8 7}$ & $\mathbf{8 1 7}$ \\
\hline
\end{tabular}

Sumber : Alfamart Cabang Cikokol 2018

Berdasarkan tabel tersebut dapat diketahui bahwa selama tiga tahun keluhan pelanggan pada Alfamart cabang Cikokol mengalami peningkatan, pada tahun 2015 jumlah keluhan pelanggan sebesar 741 orang, pada tahun 2016 jumlah pelanggan meningkat menjadi 787 orang, sedangkan pada tahun 2017 jumlah keluhan pelanggan juga meningkat menjadi 817 orang.

Berdasarkan latar belakang masalah diatas, maka penulis merumuskan masalah sebagai berikut:

1. Apakah promosi berpengaruh positif dan signifikan terhadap keputusan pembelian pada Alfamart Cabang Cikokol Tangerang?

2. Apakah harga berpengaruh negatif dan signifikan terhadap keputusan pembelian pada Alfamart Cabang Cikokol Tangerang?

3. Apakah promosi dan harga secara simultan berpengaruh positif dan signifikan terhadap keputusan pembelian pada Alfamart Cabang Cikokol Tangerang?

4. Apakah keputusan pembelian berpengaruh positif dan signifikan terhadap kepuasan pelanggan pada Alfamart Cabang Cikokol Tangerang?

5. Apakah promosi berpengaruh positif dan signifikan terhadap kepuasan pelanggan pada Alfamart Cabang Cikokol Tangerang?

6. Apakah harga berpengaruh negatif dan signifikan terhadap kepuasan pelanggan pada Alfamart Cabang Cikokol Tangerang?

7. Apakah promosi dan harga secara simultan berpengaruh positif dan signifikan terhadap kepuasan pelanggan pada Alfamart Cabang Cikokol Tangerang?

\section{METODE PENELITIAN}

Objek Penelitian ini di Alfamart Cabang Cikokol yang beralamat Jl. MH Thamrin no. 9 Tangerang. Populasi dalam penelitian ini adalah seluruh pelanggan Alfamart Cabang Cikokol dan dilihat dari jumlahnya termasuk dalam populasi yang begitu luas. Sampel penelitian ini berjumlah 100 konsumen. Metode pengumpulan data dalam penelitian ini observasi dan kuisioner. Skala yang digiunakan adalah skala Likert dan skala interval. Metode analisis data yang digunakan adalah uji validitas, uji reabilitas,uji asumsi klasik, regresi linier sederhana, regresi linier berganda, analisis jalur, uji korelasi produk momen, uji determinasi, uji signifikansi (uji t dan uji F). 


\section{HASIL PENELITIAN DAN PEMBAHASAN}

\section{A. Analisis Jalur (Path Analyisis)}

Untuk menguji pengaruh variabel moderator digunakan metode analisis jalur (Path Analysis). Analisis jalur merupakan perluasan dari analisis regresi linier. berganda, atau analisis jalur adalah penggunaan analisis regresi untuk menaksir hubungan kausalitas antar variabel yang telah ditetapkan sebelumnya berdasarkan teori (Ghozali,2012:210). Analisis jalur pada penelitian ini dapat digambarkan sebagai berikut :

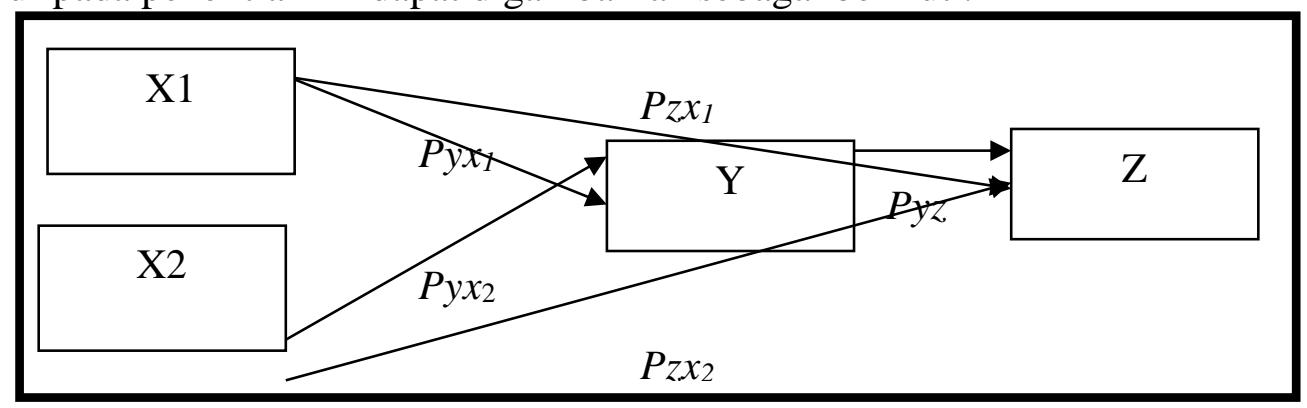

Gambar 3.1

Model Diagram Jalur Variabel $X_{1}, X_{2}, Y$ dan $Z$

Tabel 3.1

Rangkuman Hasil Pengaruh Berdasarkan Koefisien Jalur

\begin{tabular}{|c|c|c|c|c|c|}
\hline \multirow[b]{2}{*}{$\begin{array}{c}\text { Pengaruh } \\
\text { Antar Variabel }\end{array}$} & \multirow[b]{2}{*}{$\begin{array}{l}\text { Koefisien } \\
\text { Jalur }\end{array}$} & \multicolumn{4}{|c|}{ Pengaruh Kausal } \\
\hline & & Langsung & $\begin{array}{c}\text { Tidak } \\
\text { Langsung }\end{array}$ & Total & Bersama \\
\hline $\mathrm{X}_{1}$ terhadap $\mathrm{Y}$ & 0,259 & 0,259 & - & 0,259 & - \\
\hline $\mathrm{X}_{2}$ terhadap $\mathrm{Y}$ & $-0,225$ & $-0,225$ & - & $-0,225$ & - \\
\hline $\mathrm{X}_{1}$ terhadap $\mathrm{Z}$ & 0,228 & 0,228 & $\begin{array}{l}0,228 \times 0,270 \\
=0,061\end{array}$ & $\begin{array}{l}0,228+0,061 \\
=0,289\end{array}$ & - \\
\hline $\mathrm{X}_{2}$ terhadap $\mathrm{Z}$ & $-0,239$ & $-0,239$ & $\begin{array}{c}-0,239 x \\
0,270=- \\
0,064\end{array}$ & $\begin{array}{c}0,239+0,064 \\
=303\end{array}$ & - \\
\hline Y terhadap Z & 0,270 & 0,270 & - & 0,270 & - \\
\hline $\begin{array}{c}\mathrm{X}_{1}, \mathrm{X}_{2} \text { terhadap } \\
\mathrm{Y}\end{array}$ & - & - & - & - & 0,153 \\
\hline $\begin{array}{c}\mathrm{X}_{1}, \mathrm{X}_{2} \text { terhadap } \\
\mathrm{Z}\end{array}$ & - & - & - & - & 0,232 \\
\hline$\varepsilon 1$ & 0,920 & - & - & - & - \\
\hline$\varepsilon 2$ & 0,876 & - & - & - & - \\
\hline
\end{tabular}

Sumber: Hasil Pengolahan Data, 2018

\section{B. Uji Hipotesis}

Sebelum melakukan penarikan kesimpulan tentang pengaruh dari masing-masing variabel indenpenden terhadap variabel dependennya, maka perlu dilakukan pengujian hipotesis untuk membuktikan secara statistik ada tidaknya pengaruh signifikan dari variabel bebas terhadap variabel tidak bebasnya. Pengujian hipotesis dilakukan dengan dua tahap yaitu pengujian secara individual dan pengujian secara keseluruhan.

\section{Pengaruh Promosi Terhadap Keputusan Pembelian}

Hasil penelitian menunjukan bahwa promosi berpengaruh positif dan signifikan terhadap keputusan pembelian pada Alfamart Cabang Cikokol Tangerang hal ini dapat 
dilihat dari besarnya koefisen jalur sebesar 0,259 dan Nilai t hitung 2,642 >t tabel 1,984 dengan signifikan $0,010<0,05$.

\section{Pengaruh Harga Terhadap Keputusan Pembelian}

Hasil penelitian menunjukan bahwa harga berpengaruh negatif dan signifikan terhadap keputusan pembelian pada Alfamart Cabang Cikokol Tangerang hal ini dapat dilihat dari besarnya koefisen jalur sebesar -0,225 dan Nilai thitung -2,297 > t tabel 1,984 dengan signifikan $0,024<0,05$.

\section{Pengaruh Promosi dan Harga Secara Simultan Terhadap Keputusan Pembelian}

Hasil penelitian menunjukan bahwa promosi dan harga berpengaruh positif dan signifikan terhadap keputusan pembelian pada Alfamart Cabang Cikokol Tangerang hal ini dapat dilihat dari besarnya koefisen jalur sebesar 0,153 , nilai $\mathrm{F}$ hitung $8,757>\mathrm{F}$ tabel 3,09 dengan siginifikan $0,000<0,05$.

\section{Pengaruh Keputusan Pembelian Terhadap Kepuasan Pelanggan}

Hasil penelitian menunjukan bahwa keputusan pembelian berpengaruh positif dan signifikan terhadap kepuasan pelanggan pada Alfamart Cabang Cikokol Tangerang hal ini dapat dilihat dari besarnya koefisen jalur sebesar 0,270 dan Nilai t hitung sebesar $2,898>\mathrm{t}$ tabel 1,984 dengan signifikan $0,007<0,05$.

\section{Pengaruh Promosi Terhadap Kepuasan Pelanggan}

Hasil penelitian menunjukan bahwa promosi berpengaruh positif dan signifikan terhadap kepuasan pelanggan pada Alfamart Cabang Cikokol Tangerang hal ini dapat dilihat dari besarnya koefisen jalur sebesar 0,228 dan Nilai thitung 2,445>t tabel 1,984 dengan signifikan $0,016<0,05$.

\section{Pengaruh Harga Terhadap Kepuasan Pelanggan}

Hasil penelitian menunjukan bahwa harga berpengaruh negatif dan signifikan terhadap kepuasan pelanggan pada Alfamart Cabang Cikokol Tangerang hal ini dapat dilihat dari besarnya koefisen jalur sebesar -0,239 dan Nilai t hitung -2,2586 > t tabel 1,984 dengan signifikan $0,011<0,05$.

\section{Pengaruh Promosi dan Harga Secara Simultan Terhadap Kepuasan Pelanggan}

Hasil penelitian menunjukan bahwa promosi dan harga berpengaruh positif dan signifikan terhadap kepuasan pelanggan pada Alfamart Cabang Cikokol Tangerang hal ini dapat dilihat dari besarnya koefisen jalur sebesar 0,232, nilai F hitung 14,669> F tabel 3,09 dengan siginifikan 0,000 $<0,05$ dengan demikian Ho ditolak dan Ha diterima, artinya secara simultan atau bersama-sama promosi dan harga berpengaruh positif dan signifikan terhadap kepuasan pelanggan pada Alfamart Cabang Cikokol Tangerang

\section{PENUTUP}

\section{A. Kesimpulan}

Berdasarkan hasil penelitian pada Alfamart Cabang Cikokol Tangerang, maka dapat diambil kesimpulan sebagai berikut:

1. Secara parsial promosi berpengaruh positif dan signifikan terhadap keputusan pembelian pada Alfamart Cabang Cikokol Tangerang. Hal ini dapat dibuktikan oleh nilai koefisien jalur sebesar 0,259 dan nilai t hitung 2,642 > t tabel 1,984 dengan signifikan 0,010 < 0,05 . 
2. Secara parsial harga berpengaruh negatif dan signifikan terhadap keputusan pembelian pada Alfamart Cabang Cikokol Tangerang. Hal ini dapat dibuktikan oleh nilai koefisien jalur sebesar -0,225 dan nilai t hitung -2,297> t tabel -1,984 dengan signifikan 0,024< 0,05 .

3. Secara simultan promosi dan harga berpengaruh positif dan signifikan terhadap keputusan pembelian pada Alfamart Cabang Cikokol Tangerang. Hal ini dapat dibuktikan oleh nilai koefisien jalur sebesar 0,153 dan nilai $\mathrm{F}$ hitung 8,757 > F tabel 3,09 dengan siginifikan $0,000<0,05$.

4. Secara parsial keputusan pembelian berpengaruh positif dan signifikan terhadap kepuasan pelanggan pada Alfamart Cabang Cikokol Tangerang. Hal ini dapat dibuktikan oleh nilai koefisien jalur sebesar 0,270 dan nilai t hitung sebesar 2,898 > t tabel 1,984 dengan signifikan $0,007<0,05$.

5. Secara parsial promosi berpengaruh positif dan signifikan terhadap kepuasan pelanggan pada Alfamart Cabang Cikokol Tangerang. Hal ini dapat dibuktikan oleh nilai koefisien jalur sebesar 0,228 dan Nilai t hitung 2,445 > t tabel 1,984 dengan signifikan 0,016 < 0,05 .

6. Secara parsial harga berpengaruh negatif dan signifikan terhadap kepuasan pelanggan pada Alfamart Cabang Cikokol Tangerang. Hal ini dapat dibuktikan oleh nilai koefisien jalur sebesar $-0,239$ dan nilai t hitung harga $-2,2586>t$ tabel $-1,984$ dengan signifikan $0,011<0,05$.

7. Secara simultan promosi dan harga berpengaruh positif dan signifikan terhadap kepuasan pelanggan pada Alfamart Cabang Cikokol Tangerang. Hal ini dapat dibuktikan oleh nilai koefisien jalur sebesar 0,232, nilai $\mathrm{F}$ hitung 14,669 > F tabel 3,09 dengan siginifikan $0,000<0,05$.

\section{B. Saran}

Berdasarkan hasil penelitian yang didapatkan maka saran yang ingin penulis sampaikan khususnya pada Alfamart Cabang Cikokol Tangerang yaitu:

1. Untuk meningkatkan promosi maka sebaiknya perusahaan memperhatikan pemasaran langsung yang dilakukan oleh karyawannya dengan cara menawarkan produk-produk promosi secara langsung kepada pelanggan serta menginformasikan kepada pelanggan akan keunggulan produk yang ditawarkan, cara ini evektif guna meningkatkan keputusan pembelian konsumen.

2. Alfamart Cabang Cikokol Tangerang sebaiknya lebih memperhatikan kesesuaian harga yang ditawarkan dengan membandingkan harga yang ditawarkan oleh pesaingnya karena konsumen cenderung memilih produk murah dengan berkualitas yang sama.

3. Alfamart Cabang Cikokol Tangerang sebaiknya meperbanyak variasi produk yang terdisplay sehingga kebutuhan pelanggan akan produk yang di cari terpenuhi.

4. Untuk meningkatkan kepuasan pelanggan maka sebaiknya perusahaan memperhatikan harapan pelanggan yaitu dengan cara memberikan promosi yang menarik, menetapkan harga yang sesuai dan meningkatkan kualitas pelayanan sehingga harapan pelanggan dapat terpenuhi dan menciptakan kepuasan bagi pelanggan.

\section{DAFTAR PUSTAKA}

Alma, 2013, Manajemen Pemasaran Dan Pemasaran Jasa, CV Alfabeta, Bandung.

Arikunto, 2010, Prosedur Penelitian: Suatu Pendekatan Praktis. Edisi Revisi, Rineka Cipta. Jakarta.

Assauri, 2012, Manajemen Pemasaran, Rajawali Pers, Jakarta.

Atik dan Ratminto, 2012, Manajemen Pelayanan. Pustaka Pelajar, Yogyakarta. 
Daryanto, 2011, Strategi Menaklukkan. Pasar Melalui Riset Ekuitas dan Perilaku Merek. Cetakan Ketiga. Gramedia, Jakarta.

Effendi M. Guntur, 2010, Transformasi Manajemen Pemasaran+Membangun. Citra Negara. Sagung Seto, Jakarta.

Ghozali, 2012, Aplikasi Analisis Multivariate Dengan Program SPSS. Badan Penerbit Undip. Semarang.

Hasibuan, 2009, Manajemen Sumber Daya Manusia, Edisi Revisi, PT Bumi Aksara, Jakarta. Hasan, 2009, Marketing, Media Pressindo, Yogyakarta.

Jhon D. Millet, 2012, Management in the public service: The quest for effective performance. New York: McGraw-Hill.

Rangkuty, 2009, Riset Pemasaran, Gramedia pustaka Utama, Jakarta.

Robbins dan Coulter, 2014, Manajemen, Edisi ke sepuluh jilid 1, Erlangga, Jakarta.

Rosvita, 2010, Analisis Pengaruh Kualitas Produk, Harga, Promosi, dan Cuaua terhadap Keputusan Pembelian Teh siap Minum dalam Kemasan Merek Teh Botol Sosro. Fakultas Ekonomi Universitas Diponegoro Semarang.

Saladin, 2011, Manajemen Strategi dan Kebijakan Perusahaan, Edisi Lima, Linda Karya, Bandung.

Safroni, 2012, Manajemen dan Reformasi Pelayanan Publik dalam. Konteks Birokrasi Indonesia. Aditya Media Publishing, Surabaya

Shinta Agustina, 2011, Perilaku Konsumen: Afeksi Konsumen, Lab, Manajemen Agribisnis/Fakultas Pertanian, Universitas Brawijaya, Malang.

Sugiyono, 2015, Metodologi Penelitian Manajemen, Alfabeta, Bandung.

Supardi, 2013, Aplikasi Statistik Dalam Penelitian, PT Prima Ufuk Semesta, Jakarta.

Supranto, 2012, Metode Riset Aplikasinya Dalam Pemasaran, Lembaga Penerbitan Fakultas Ekonomi Universitas Indonesia, Jakarta.

Swastha dan Irawan, 2011, Pemasaran Modern, Liberty, Yogyakarta.

Tjiptono, 2014, Pemasaran Jasa, Andi Offset, Yogyakarta. 